\title{
Construct $\mathrm{Fe}^{2+}$ species and Au particles for significantly enhanced photoelectrochemical performance of $\mathrm{a}-\mathrm{Fe}_{2} \mathrm{O}_{3}$ by ion implantation
}

\author{
Dong He, Xianyin Song, Zunjian Ke, Xiangheng Xiao* and Changzhong Jiang
}

\begin{abstract}
Photoelectrochemical (PEC) water splitting is a promising approach to producing $\mathrm{H}_{2}$ and $\mathrm{O}_{2}$. Hematite (a$\left.\mathrm{Fe}_{2} \mathrm{O}_{3}\right)$ is considered one of the most promising photoelectrodes for PEC water splitting, due to its good photochemical stability, non-toxicity, abundance in earth, and suitable bandgap $\left(E_{\mathrm{g}} \sim 2.1 \mathrm{eV}\right)$. However, the PEC water splitting efficiency of hematite is severely hampered by its short hole diffusion length (2-4 nm), poor conductivity, and ultrafast recombination of photogenerated carriers (about $10 \mathrm{ps).} \mathrm{Here,}$ we show a novel and effective method for significantly improving the PEC water splitting performance of hematite by $\mathrm{Au}$ ion implantation and the following high-temperature annealing process. Based on a series of characterizations and analyses, we have found $\mathrm{Fe}^{2+}$ species and tightly attached $\mathrm{Au}$ particles were produced at $\mathrm{Au}$-implanted hematite. As a result, the charge separation and charge injection efficiency of Auimplanted $\mathrm{Fe}_{2} \mathrm{O}_{3}$ are markedly increased. The photocurrent density of optimized Au-implanted $\mathrm{Fe}_{2} \mathrm{O}_{3}$ could reach $1.16 \mathrm{~mA} \mathrm{~cm}$ cm $^{-2}$ at $1.5 \mathrm{~V}$ vs. RHE which was nearly 300 times higher than that of the pristine $\left.\mathrm{Fe}_{2} \mathrm{O}_{3}(4 \mu \mathrm{A} \mathrm{cm})^{-2}\right)$. Furthermore, the Au-implanted $\mathrm{Fe}_{2} \mathrm{O}_{3}$ photoelectrode exhibited great stability for the 8-hour PEC water splitting test without photocurrent decay.
\end{abstract}

Keywords: hematite, $\mathrm{Fe}^{2+}$ species, photoelectrochemical water splitting, ion implantation

\section{INTRODUCTION}

Energy and pollution problems have attracted more and more attention in modern society. It is necessary and unavoidable to adjust the energy structure by replacing traditional fossil energy with renewable energy. Photo- electrochemical (PEC) water splitting is a promising approach to producing $\mathrm{H}_{2}$ and $\mathrm{O}_{2}$ [1]. Since Fujishima and Honda [2] firstly used $\mathrm{TiO}_{2}$ as a photoelectrode to produce $\mathrm{H}_{2}$ and $\mathrm{O}_{2}$ under $\mathrm{UV}$ illumination, many kinds of semiconductors like $\alpha-\mathrm{Fe}_{2} \mathrm{O}_{3}, \mathrm{C}_{3} \mathrm{~N}_{4}, \mathrm{BiVO}_{4}$, etc. have been intensively researched as potential photoelectrodes [3-8]. Even though many efforts have been made to improve the PEC water splitting performance of these photoelectrodes, the real efficiency is still far below the theoretical calculation value [9-11]

Among these materials, hematite $\left(\alpha-\mathrm{Fe}_{2} \mathrm{O}_{3}\right)$ is considered as one of the most promising photoelectrodes for PEC water splitting, due to its good photochemical stability, non-toxicity, abundance in earth, and suitable bandgap for PEC water splitting $\left(E_{\mathrm{g}} \sim 2.1 \mathrm{eV}\right)$ [9]. However, hematite is a kind of Mott insulator [12,13], so that the PEC performance of hematite is severely hampered by its short hole diffusion length (about 2-4 nm), poor conductivity and ultrafast recombination of photogenerated carriers (about 10 ps) [9]. Different strategies were developed to deal with those problems, including: (1) doping hematite with heteroatom ( $\mathrm{Sn}, \mathrm{Ti}, \mathrm{Si}$, etc.) to improve free carrier density [14-18]; (2) controlling morphology to shorten transfer distance of carriers, hematites with various morphology, such as nanowires, nanotubes, and nanoporous films were synthesized and exhibited improved performances [17-20]; (3) introducing self-doped $\mathrm{Fe}^{2+}$ species to improve the conductivity of hematite [21-25]; (4) combining with the noble metal $(\mathrm{Au}, \mathrm{Pt}$, etc.) to improve the surface charge separation efficiency [24-28]. Although many novel and excellent PEC systems have been designed and exhibited improved

Department of Physics and Key Laboratory of Artificial Micro- and Nano-structures of Ministry of Education, Hubei Nuclear Solid Physics Key Laboratory and Center for Ion Beam Application, Wuhan University, Wuhan 430072, China

* Correspondence author (email: xxh@whu.edu.cn) 
performances, an effective and scalable preparation method to integrate several strategies is yet to be developed.

Ion implantation has been a typical surface modification technology to tune the electronic properties of semiconductor materials in industry for decades [29]. By accurately controlling the acceleration voltage and implantation dosage, we can uniformly and precisely dope various kinds of materials with heteroatoms to change their electrical and mechanical surface properties. In our previous work, we used ion implantation to fabricate $\mathrm{N}$ doped $\mathrm{TiO}_{2}$ and realized high-efficiency visible light PEC water splitting [30].

Herein, we report a novel and effective method that improves the PEC water splitting performance of hematite by $\mathrm{Au}$ ion implantation and the following hightemperature annealing treatments. Based on a series of characterization and analyses, we have found $\mathrm{Fe}^{2+}$ species and $\mathrm{Au}$ particles were formed at Au-implanted hematite. $\mathrm{Fe}^{2+}$ species and tightly attached $\mathrm{Au}$ particles led to a remarkable improvement of photoinduced charge separation and charge injection efficiency. The charge injection efficiency was greatly increased from $2 \%$ (pristine $\mathrm{Fe}_{2} \mathrm{O}_{3}$ ) to $89 \%$ (optimized Au-implanted hematite) at $1.5 \mathrm{~V} v s$. reversible hydrogen electrode (RHE). Therefore, the photocurrent density was enhanced by nearly 300 times, and the incident photon-to-current conversion efficiency (IPCE) of optimized Au-implanted hematite can reach $25.8 \%$ at $350 \mathrm{~nm}$, which is much higher than the IPCE value of pristine $\mathrm{Fe}_{2} \mathrm{O}_{3}$ (0.57\%). In addition, $\mathrm{Au}$ implanted $\mathrm{Fe}_{2} \mathrm{O}_{3}$ photoelectrode exhibited excellent stability in the 8-hour PEC testing.

\section{EXPERIMENTAL SECTION}

\section{Preparation of $\mathrm{Fe}_{2} \mathrm{O}_{3}$ and Au-implanted $\mathrm{Fe}_{2} \mathrm{O}_{3}$}

Akageneite $(\beta-\mathrm{FeOOH})$ was first grown on a fluorinedoped tin oxide glass (FTO) using a reported hydrothermal method [31]. In a typical experiment, $1.378 \mathrm{~g}$ ferric chloride $\left(\mathrm{FeCl}_{3} \cdot 6 \mathrm{H}_{2} \mathrm{O}\right)$ and $2.89 \mathrm{~g}$ sodium nitrate $\left(\mathrm{NaNO}_{3}\right)$ were added to $34 \mathrm{~mL}$ deionized water and the mixture was magnetically stirred for $5 \mathrm{~min}$. Then the aqueous solution was adjusted to $\mathrm{pH} 1.5$ with $\mathrm{HCl}$ and further subjected to magnetic stirring for another $10 \mathrm{~min}$. The precursor solution was added to a $50-\mathrm{mL}$ Teflonlined stainless steel autoclave. A piece of FTO glass slide, having been washed with acetone, ethanol, and deionized water and blown dry quickly with $\mathrm{N}_{2}$ air, was put into the autoclave where it was heated at $95^{\circ} \mathrm{C}$ for $4 \mathrm{~h}$ in an oven and naturally cooled down to ambient temperature. Then a uniform yellow layer of $\beta$-FeOOH could grow on FTO glass substrate. It was taken out and washed with deionized water and blown dry quickly with air. Subsequently, $\mathrm{Au}$ ions were implanted into $\beta-\mathrm{FeOOH}$ at $30 \mathrm{kV}$ with different ion dosages $\left(1 \times 10^{16}, 2.5 \times 10^{16}, 5 \times 10^{16}, 1 \times 10^{17}\right.$ ions $\mathrm{cm}^{-2}$ ) by metal vapor vacuum arc (MEVVA) ion source implanter. Finally, pristine $\beta-\mathrm{FeOOH}$ and $\mathrm{Au}-$ implanted $\beta-\mathrm{FeOOH}$ were annealed in air at different temperatures for $2 \mathrm{~h}$ in a horizontal quartz-tube furnace.

\section{Characterization of $\mathrm{Fe}_{2} \mathrm{O}_{3}$ and Au-implanted $\mathrm{Fe}_{2} \mathrm{O}_{3}$}

The field-emission scanning electron microscopy images (FE-SEMs) were collected by JEOL S-4800 (Japan). X-ray diffraction (XRD) was carried out on Bruker AXS, D8 Advance X-ray powder diffractometer with $\mathrm{Cu}-\mathrm{Ka}$ radiation ( $\lambda=0.15418 \mathrm{~nm}$, Germany). Raman measurements were performed by laser confocal micro Raman spectrometers (Renishaw inVia, Renishaw, UK) with laser excited at $488 \mathrm{~nm}$. X-ray photoelectron spectroscopy (XPS) measurements were done on a Thermo Scientific ESCALAB $250 \mathrm{Xi}$ system (USA) with $\mathrm{Al} \mathrm{Ka}(1486.6 \mathrm{eV})$ as the radiation source and all spectra were calibrated using the $\mathrm{C}$ 1s peak with a value of $284.8 \mathrm{eV}$. The UV-vis absorption spectra were collected by SHIMADZU UV-2550 UVvis spectrophotometer. Mossbauer spectroscopy was performed at room temperature by a RiKon-5A (Germany) proportional counter with gas mixture of $96 \% \mathrm{He}$ and $4 \% \mathrm{CH}_{4} \cdot \mathrm{A}^{57} \mathrm{Co}$ in $\mathrm{Rh}$ matrix source with activity of $25 \mathrm{mCi}\left(1 \mathrm{mCi}=37 \times 10^{6} \mathrm{~Bq}\right)$ was used for excitation.

\section{Photoeletrochemical measurements}

PEC measurements of the hematite photoanodes were carried out in a conventional three-electrode electrochemical cell using Pt wire as the counter electrode and $\mathrm{Ag} / \mathrm{AgCl}$ electrode as the reference electrode. A solution of $1.0 \mathrm{~mol} \mathrm{~L}^{-1} \mathrm{NaOH}$ ( $\mathrm{pH}$ 13.6) was used as the electrolyte (purged with Ar). All linear sweep voltammograms were measured by a computer-controlled electrochemical workstation (CHI 650E) under a $500 \mathrm{~W}$ xenon lamp with an AM 1.5 global filter at an irradiation intensity of $100 \mathrm{~mW} \mathrm{~cm}{ }^{-2}$. IPCE spectra were obtained by using a xenon lamp (Newport model 66902) coupled with a grating monochromator (Newport Model 74125) and a power meter (Newport model 2936-R) in the wavelength range from 300 to $650 \mathrm{~nm}$ at an applied potential of $1.5 \mathrm{~V}$ (vs. RHE). The charge separation efficiency was measured under $458 \mathrm{~nm}$ monochromatic light and $\mathrm{H}_{2} \mathrm{O}_{2}$ was used as the hole scavenger in the electrolyte. The charge injection efficiency was measured by using the $\mathrm{H}_{2} \mathrm{O}_{2}$ as the hole scavenger in the electrolyte [27]. 


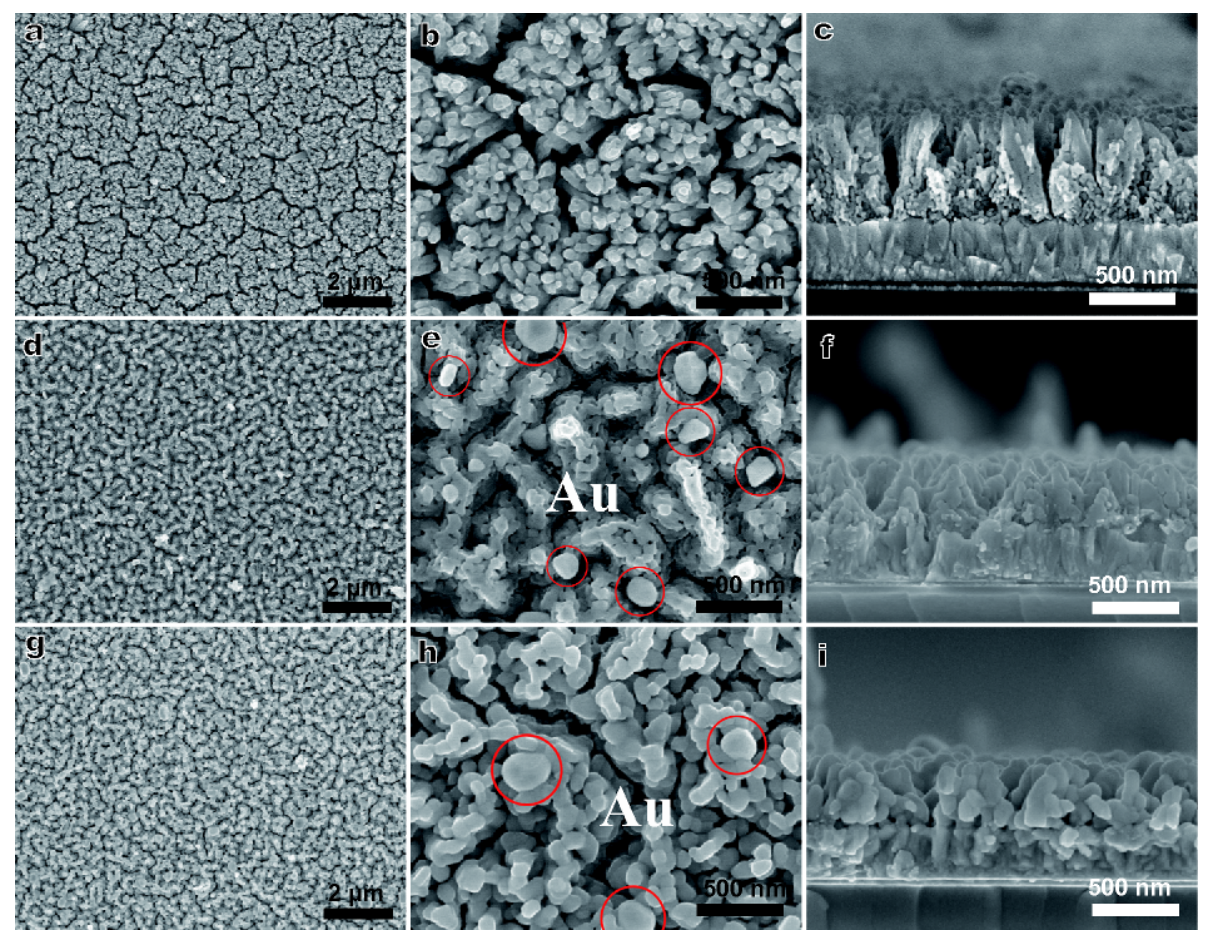

Figure 1 The top view and cross-sectional SEM images of $\beta$-FeOOH annealed at $550^{\circ} \mathrm{C}$ for $2 \mathrm{~h}$ (pristine $\left.\mathrm{Fe}_{2} \mathrm{O}_{3}\right)(\mathrm{a}-\mathrm{c}$ ), Au ion implanted $\beta$-FeOOH at $30 \mathrm{kV}$ with $5 \times 10^{16}$ ions $\mathrm{cm}^{-2}$ and annealed at $550^{\circ} \mathrm{C}$ for $2 \mathrm{~h}\left(\mathrm{Au}-\mathrm{Fe}_{2} \mathrm{O}_{3}-550\right)(\mathrm{d}-\mathrm{f})$, and $\mathrm{Au}$ ion implanted $\beta-\mathrm{FeOOH}$ at $30 \mathrm{kV}$ with $5 \times 10^{16}$ ions cm ${ }^{-2}$ and annealed at $550^{\circ} \mathrm{C}$ for $2 \mathrm{~h}$ and following at $700^{\circ} \mathrm{C}$ for further $15 \mathrm{~min}\left(\mathrm{Au}-\mathrm{Fe}_{2} \mathrm{O}_{3}-700\right)(\mathrm{g}-\mathrm{i})$.

\section{RESULTS AND DISCUSSION}

$\beta$-FeOOH was synthesized with a hydrothermal method and conducted with Au implantation. Subsequently, the pristine $\beta-\mathrm{FeOOH}$ sample and $\mathrm{Au}$ ion implanted akageneite samples were annealed at $550^{\circ} \mathrm{C}$ in air for $2 \mathrm{~h}$ to be converted into hematite $\left(\mathrm{Fe}_{2} \mathrm{O}_{3}, \mathrm{Au}-\mathrm{Fe}_{2} \mathrm{O}_{3}-550\right)$. As shown in Fig. 1, FE-SEM was used to characterize the morphology of pristine $\mathrm{Fe}_{2} \mathrm{O}_{3}$ and $\mathrm{Au}$-implanted $\mathrm{Fe}_{2} \mathrm{O}_{3}$. The pristine $\mathrm{Fe}_{2} \mathrm{O}_{3}$ exhibits smooth and uniform nanorod morphology with a length of $650 \mathrm{~nm}$ (Fig. 1a-c). After Au ion implantation and thermal annealing (Fig. 1d, e), the surface of hematite became rougher and more compact. It can be seen clearly that the implanted $\mathrm{Au}$ atoms recrystallized and grew to Au particles on the surface and the gaps of hematite [32]. Meanwhile, the thickness of hematite film was reduced to about $400 \mathrm{~nm}$ (Fig. 1f), which can be attributed to the fact that the surface hematite layer was sputtered by high energy implanted $\mathrm{Au}$ ions [33]. After annealing of Au-implanted $\mathrm{Fe}_{2} \mathrm{O}_{3}$ at higher temperatures $\left(\right.$ at $700^{\circ} \mathrm{C}$ for another $15 \mathrm{~min}(\mathrm{Au}-$ $\left.\mathrm{Fe}_{2} \mathrm{O}_{3}-700\right)$ ), the surface of hematite became macrogranular (Fig. 1g, h). Meantime, the thickness of hematite was further reduced to $360 \mathrm{~nm}$ due to the regrowth of hematite [34], and the contact properties between $\mathrm{Au}$ particles and hematite for $\mathrm{Au}-\mathrm{Fe}_{2} \mathrm{O}_{3}-700$ are better than those of the $\mathrm{Au}-\mathrm{Fe}_{2} \mathrm{O}_{3}-550$ (Fig. 1e, h). Tightly attached $\mathrm{Au}$ particles could serve as the charge mediator, and therefore the photogenerated carriers could efficiently and fast transport through the hematite and electrolyte. Furthermore, accompanied by the reduction of hematite thickness, the optical absorption intensities of $\mathrm{Au}-\mathrm{Fe}_{2} \mathrm{O}_{3}-$ 550 and $\mathrm{Au}-\mathrm{Fe}_{2} \mathrm{O}_{3}-700$ are weaker than the pristine $\mathrm{Fe}_{2} \mathrm{O}_{3}$ as shown in Fig. S1.

As illustrated in Fig. 2a, b, Raman and XRD measurements were performed to characterize the composition and crystalline phases of pristine $\mathrm{Fe}_{2} \mathrm{O}_{3}$ and $\mathrm{Au}$ ion implanted $\mathrm{Fe}_{2} \mathrm{O}_{3}\left(\mathrm{Au}-\mathrm{Fe}_{2} \mathrm{O}_{3}-550\right.$ and $\left.\mathrm{Au}-\mathrm{Fe}_{2} \mathrm{O}_{3}-700\right)$. The prominent Raman peaks for pristine $\mathrm{Fe}_{2} \mathrm{O}_{3}$ (Fig. 2a) correspond to $A_{1 \mathrm{~g}}\left(225\right.$ and $\left.498 \mathrm{~cm}^{-1}\right)$ and $E_{\mathrm{g}}(247,293$, 299,412 , and $613 \mathrm{~cm}^{-1}$ ) modes of the crystalline hematite phase, which is consistent with a previous report [35]. Meanwhile, Raman spectra of $\mathrm{Au}-\mathrm{Fe}_{2} \mathrm{O}_{3}-550$ and $\mathrm{Au}-$ $\mathrm{Fe}_{2} \mathrm{O}_{3}-700$ are same as that of pristine $\mathrm{Fe}_{2} \mathrm{O}_{3}$ [36], indicating that there is no phase change at $\mathrm{Au}$ ion implanted $\mathrm{Fe}_{2} \mathrm{O}_{3}$. XRD spectra results also confirmed the conclusion of Raman studies (Fig. 2b) (JCPDS 33-0664) [37]. Moreover, the XRD diffraction peak located at $38.18^{\circ}$ (JCPDS 04-0784) indicates that the crystalline $\mathrm{Au}$ 

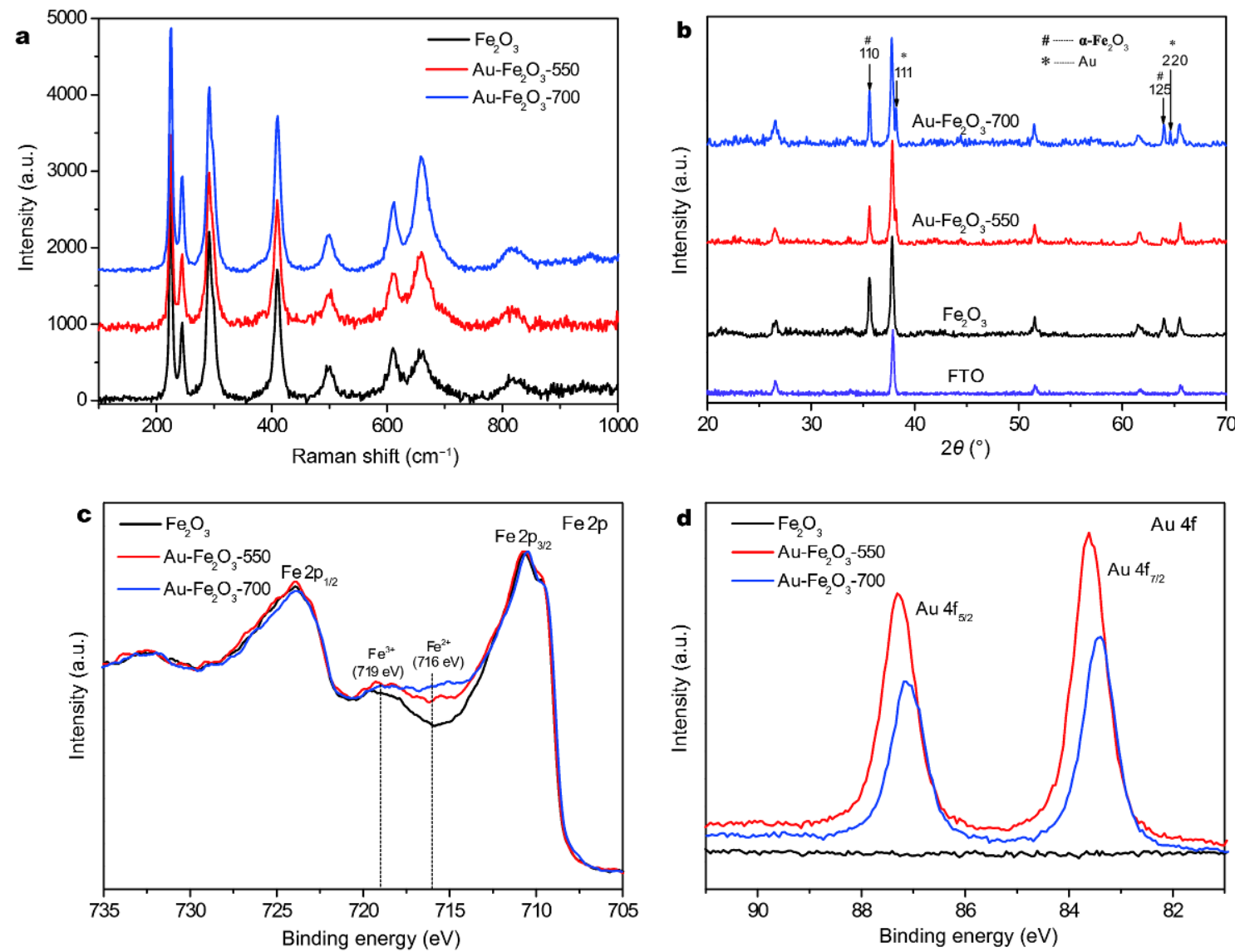

Figure 2 (a) Raman spectra of pristine $\mathrm{Fe}_{2} \mathrm{O}_{3}, \mathrm{Au}-\mathrm{Fe}_{2} \mathrm{O}_{3}-550, \mathrm{Au}-\mathrm{Fe}_{2} \mathrm{O}_{3}-700$; (b) XRD spectra of FTO, $\mathrm{Fe}_{2} \mathrm{O}_{3}, \mathrm{Au}-\mathrm{Fe}_{2} \mathrm{O}_{3}-550$, and $\mathrm{Au}-\mathrm{Fe}_{2} \mathrm{O}_{3}-700$; XPS $\mathrm{Fe} 2 \mathrm{p}(\mathrm{c})$ and $\mathrm{Au} 4 \mathrm{f}(\mathrm{d})$ spectra of pristine $\mathrm{Fe}_{2} \mathrm{O}_{3}, \mathrm{Au}-\mathrm{Fe}_{2} \mathrm{O}_{3}-550, \mathrm{Au}-\mathrm{Fe}_{2} \mathrm{O}_{3}-700$.

phase was produced in $\mathrm{Au}-\mathrm{Fe}_{2} \mathrm{O}_{3}-550$ and $\mathrm{Au}-\mathrm{Fe}_{2} \mathrm{O}_{3}-700$. Impressively, compared with $\mathrm{Au}-\mathrm{Fe}_{2} \mathrm{O}_{3}-550$, after further $700^{\circ} \mathrm{C}$ annealing treatment, the intensity of hematite (125) peak at $66.02^{\circ}$ was obviously enhanced and a new $\mathrm{Au}(220)$ peak at $64.58^{\circ}$ appeared in the $\mathrm{Au}-\mathrm{Fe}_{2} \mathrm{O}_{3}-700$ sample. The $\mathrm{Au}(220)$ peak is very close to the hematite (125) peak, and the lattice mismatch between $\mathrm{Au}$ (220) and hematite (125) is only 3.05\% [38]. Therefore, the contact properties between $\mathrm{Au}$ particles and hematite at $\mathrm{Au}-\mathrm{Fe}_{2} \mathrm{O}_{3}-700$ are much tighter than those of $\mathrm{Au}-\mathrm{Fe}_{2} \mathrm{O}_{3}-$ 550 , which was in agreement with SEM images shown in Fig. 1e, h. The strong contact of noble metal and semiconductor would be beneficial for surface photoinduced charge separation $[27,39]$.

XPS was employed to investigate the chemical composition and the change of chemical state on the surface. The survey spectra of $\mathrm{Fe}_{2} \mathrm{O}_{3}, \mathrm{Au}-\mathrm{Fe}_{2} \mathrm{O}_{3}-550$, and $\mathrm{Au}-$ $\mathrm{Fe}_{2} \mathrm{O}_{3}-700$ were shown in Fig. S2. As shown in Fig. 2c, the two peaks centered at 711.4 and $724.7 \mathrm{eV}$ of pristine $\mathrm{Fe}_{2} \mathrm{O}_{3}, \mathrm{Au}-\mathrm{Fe}_{2} \mathrm{O}_{3}-550$, and $\mathrm{Au}-\mathrm{Fe}_{2} \mathrm{O}_{3}-700$ are corre- sponding to $\mathrm{Fe} 2 \mathrm{p}_{3 / 2}$ and $2 \mathrm{p}_{1 / 2}$ of $\mathrm{Fe}^{3+}$, respectively [40]. The Fe $2 p_{3 / 2}$ satellite peaks located at about $719 \mathrm{eV}$ are also attributed to the $\mathrm{Fe}^{3+}$ specie [41]. More importantly, the satellite peaks located at $716 \mathrm{eV}$, which can be attributed to $\mathrm{Fe}^{2+}$ species [21], were found in $\mathrm{Au}-\mathrm{Fe}_{2} \mathrm{O}_{3}-550$ and $\mathrm{Au}-\mathrm{Fe}_{2} \mathrm{O}_{3}-700$ samples, but not in pristine $\mathrm{Fe}_{2} \mathrm{O}_{3}$. This suggests that $\mathrm{Fe}^{2+}$ species were produced in $\mathrm{Au}$ $\mathrm{Fe}_{2} \mathrm{O}_{3}-550$ and $\mathrm{Au}-\mathrm{Fe}_{2} \mathrm{O}_{3}-700[21,40]$. In order to further analyze the oxidation states of $\mathrm{Fe}$ element, Mossbauer measurement was also used to characterize the chemical states of the iron element for $\mathrm{Au}-\mathrm{Fe}_{2} \mathrm{O}_{3}-550$. As shown in Fig. S3, the spectroscopy shows a typical 6-line pattern for hematite. Meanwhile, the $\mathrm{Fe}^{2+}$ signal was found after fitting the Mossbauer spectroscopy, which consists with the result of XPS $[42,43]$. The formation of $\mathrm{Fe}^{2+}$ species in Au-implanted hematite can be attributed to the preferential oxygen sputtering during the Au ion implantation [44]. In previous work, it was reported that moderate $\mathrm{Fe}^{2+}$ sites could improve the conductivity of hematite and enhance the PEC performance $[21,45]$. Meanwhile, the 

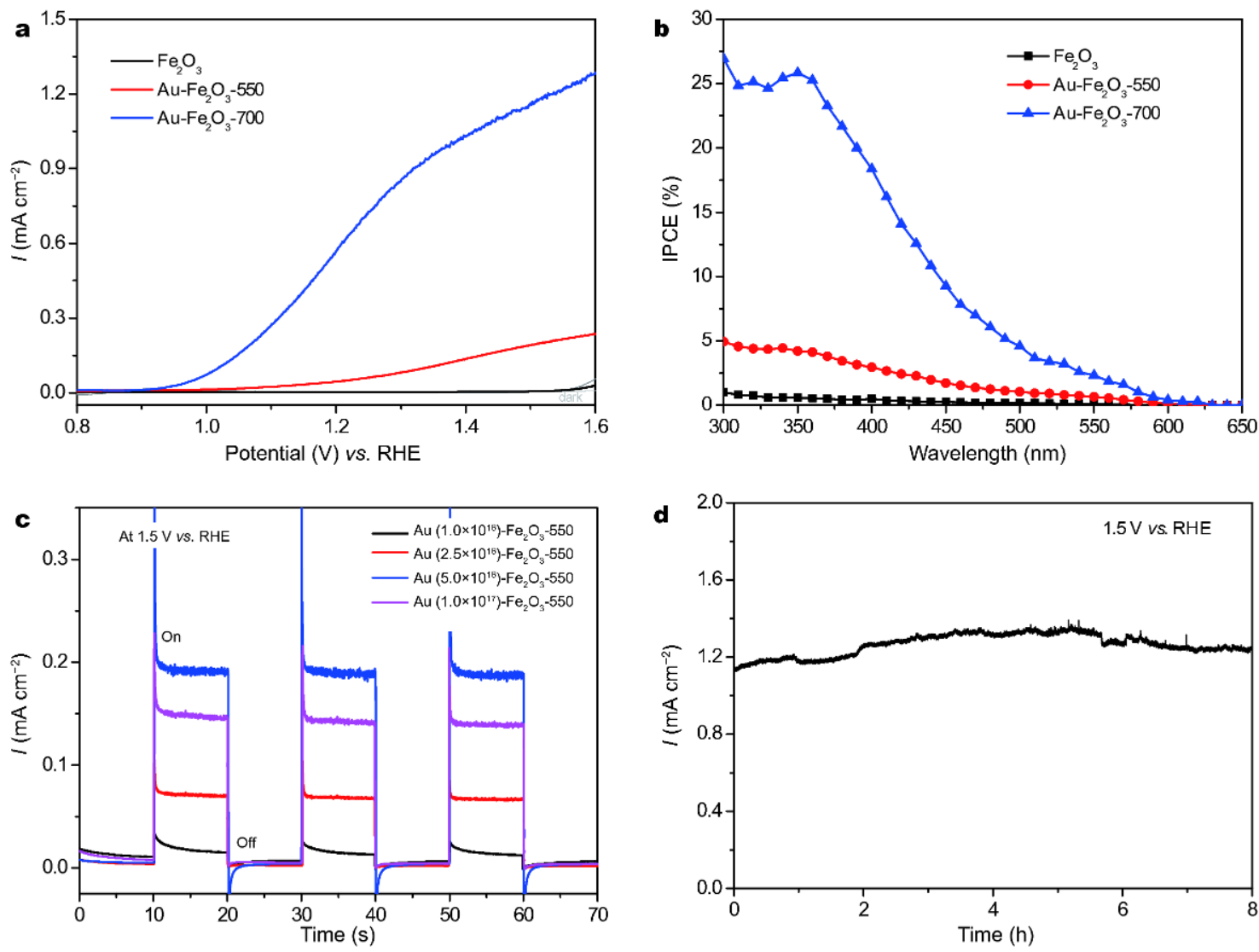

Figure 3 (a) Linear sweep voltammetry curves of pristine $\mathrm{Fe}_{2} \mathrm{O}_{3}, \mathrm{Au}-\mathrm{Fe}_{2} \mathrm{O}_{3}-550, \mathrm{Au}-\mathrm{Fe}_{2} \mathrm{O}_{3}-700$ under simulated AM $1.5 \mathrm{G}$ illumination; (b) IPCE spectra collected at $1.5 \mathrm{~V} v$ s. RHE; (c) chopped photocurrent $I-t$ curves under AM $1.5 \mathrm{G}$ illumination of different Au implantation dosages at the same annealing temperature of $550^{\circ} \mathrm{C}$ for $2 \mathrm{~h}$; (d) photocurrent $I-t$ curves of $\mathrm{Au}-\mathrm{Fe}_{2} \mathrm{O}_{3}-700$ at $1.5 \mathrm{~V} v \mathrm{~s}$. RHE for $8 \mathrm{~h}$ under simulated AM $1.5 \mathrm{G}$ illumination.

XPS Au $4 \mathrm{f}$ core-level spectra were also measured for pristine $\mathrm{Fe}_{2} \mathrm{O}_{3}, \mathrm{Au}-\mathrm{Fe}_{2} \mathrm{O}_{3}-550$, and $\mathrm{Au}-\mathrm{Fe}_{2} \mathrm{O}_{3}-700$ (Fig. 3d). The peaks located at 83.7 and $87.3 \mathrm{eV}$ are consistent with $\mathrm{Au}^{0} 4 \mathrm{f}_{7 / 2}$ and $4 \mathrm{f}_{5 / 2}$ peaks [46].

PEC measurements of the hematite photoanodes were carried out in a conventional three-electrode electrochemical cell using Pt wire as the counter electrode and $\mathrm{Ag} / \mathrm{AgCl}$ electrode as the reference electrode. A $1 \mathrm{~mol} \mathrm{~L}^{-1}$ $\mathrm{NaOH}$ solution ( $\mathrm{pH}$ 13.6) was used as the electrolyte. The measured potentials vs. $\mathrm{Ag} / \mathrm{AgCl}$ were converted to a RHE scale according to the Nernst equation [47]:

$$
E_{\mathrm{RHE}}=E_{\mathrm{Ag} / \mathrm{AgCl}}+E_{\mathrm{Ag} / \mathrm{AgCl}}^{\mathrm{o}}+0.059 \times \mathrm{pH},
$$

where $E_{\mathrm{Ag} / \mathrm{AgCl}}^{\mathrm{o}}=0.1976 \mathrm{~V}$ at $25^{\circ} \mathrm{C}, E_{\mathrm{Ag} / \mathrm{AgCl}}$ is the experimentally measured potential against the $\mathrm{Ag} / \mathrm{AgCl}$ reference electrode, and $E_{\mathrm{RHE}}$ is the converted potential $v s$. RHE. Linear sweep voltammetry curves of the pristine $\mathrm{Fe}_{2} \mathrm{O}_{3}, \mathrm{Au}-\mathrm{Fe}_{2} \mathrm{O}_{3}-550$, and $\mathrm{Au}-\mathrm{Fe}_{2} \mathrm{O}_{3}-700$ are shown in Fig. 3a. The photoresponse of pristine $\mathrm{Fe}_{2} \mathrm{O}_{3}$ is very weak, only $4 \mu \mathrm{A} \mathrm{cm}^{-2}$ at $1.5 \mathrm{~V} v$ s. RHE. By contrast, the Au$\mathrm{Fe}_{2} \mathrm{O}_{3}-550$ and $\mathrm{Au}-\mathrm{Fe}_{2} \mathrm{O}_{3}-700$ exhibited remarkable im- provements, and the corresponding photocurrent density can reach 0.19 and $1.16 \mathrm{~mA} \mathrm{~cm}^{-2}$ at $1.5 \mathrm{~V} v$ s. RHE, which was nearly 50 and 300 times higher than that of the pristine $\mathrm{Fe}_{2} \mathrm{O}_{3}$, respectively.

IPCE measurements were tested for pristine $\mathrm{Fe}_{2} \mathrm{O}_{3}$ and $\mathrm{Au}$-implanted samples under the potential of $1.5 \mathrm{~V} v s$. RHE. IPCE values were calculated from the photocurrent densities obtained under different wavelengths in a range from 300 to $650 \mathrm{~nm}$, and expressed as the following equation [17]:

$$
\operatorname{IPCE}=(1240 \times I) /\left(\lambda \times J_{\text {light }}\right),
$$

where $I\left(\mathrm{~mA} \mathrm{~cm}^{-2}\right)$ is the photocurrent density, $\lambda(\mathrm{nm})$ is the incident wavelength, and $J_{\text {light }}\left(\mathrm{mW} \mathrm{cm}^{-2}\right)$ is the power density of irradiance at a specific wavelength. As shown in Fig. 3b, the total IPCE value of pristine $\mathrm{Fe}_{2} \mathrm{O}_{3}$ is lower than $1 \%$ across the entire test range $(300-650 \mathrm{~nm})$, which is consistent with the negligible photocurrent density shown in Fig. 3a. Significantly, the IPCE is $4.2 \%$ for $\mathrm{Au}-$ $\mathrm{Fe}_{2} \mathrm{O}_{3}-550$ and $25.8 \%$ for $\mathrm{Au}-\mathrm{Fe}_{2} \mathrm{O}_{3}-700$ at $350 \mathrm{~nm}$. Particularly, the IPCE of $\mathrm{Au}-\mathrm{Fe}_{2} \mathrm{O}_{3}-700$ still maintains more 

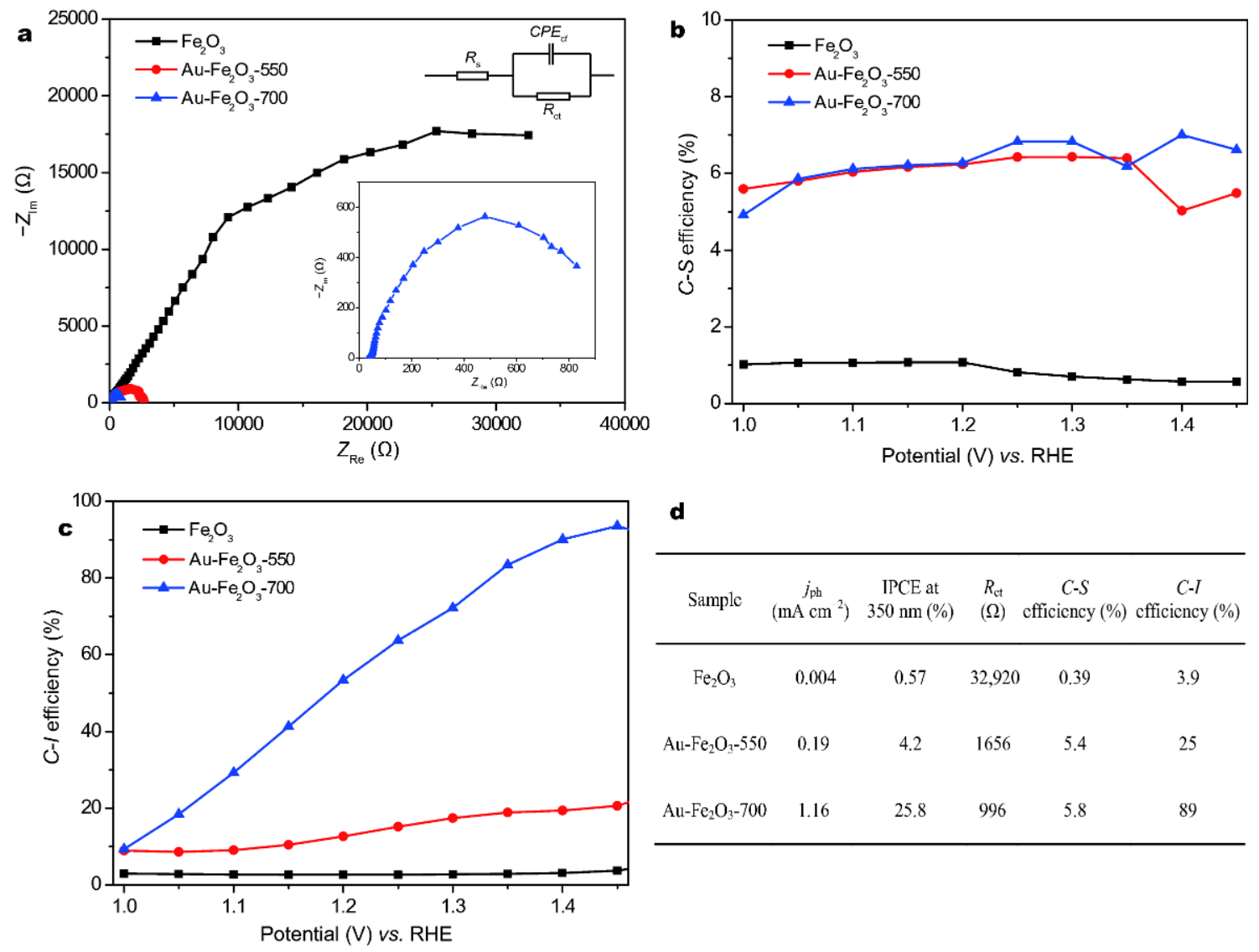

d

\begin{tabular}{cccccc}
\hline Sample & $\begin{array}{c}j_{\mathrm{ph}} \\
\left(\mathrm{mA} \mathrm{cm}^{2}\right)\end{array}$ & $\begin{array}{c}\text { IPCE at } \\
350 \mathrm{~nm}(\%)\end{array}$ & $\begin{array}{c}R_{\mathrm{ct}} \\
(\Omega)\end{array}$ & $\begin{array}{c}C-S \\
\text { cfficiency }(\%)\end{array}$ & $\begin{array}{c}C-I \\
\text { cfficiency }(\%)\end{array}$ \\
\hline $\mathrm{Fe}_{2} \mathrm{O}_{3}$ & 0.004 & 0.57 & 32,920 & 0.39 & 3.9 \\
$\mathrm{Aul}_{-\mathrm{Fe}_{2} \mathrm{O}_{3}-550}$ & 0.19 & 4.2 & 1656 & 5.4 & 25 \\
$\mathrm{Au}^{-\mathrm{Fe}_{2} \mathrm{O}_{3}-700}$ & 1.16 & 25.8 & 996 & 5.8 & 89 \\
\hline
\end{tabular}

Figure 4 (a) Nyquist plots of pristine $\mathrm{Fe}_{2} \mathrm{O}_{3}, \mathrm{Au}-\mathrm{Fe}_{2} \mathrm{O}_{3}-550$ and $\mathrm{Au}-\mathrm{Fe}_{2} \mathrm{O}_{3}-700$ at a potential of $1.5 \mathrm{~V}$ (vs. RHE) under simulated AM $1.5 \mathrm{G}$ illumination. The inset shows magnified Nyquist plot of Au- $\mathrm{Fe}_{2} \mathrm{O}_{3}-700$. (b) Charge separation efficiency and (c) charge injection efficiency of pristine $\mathrm{Fe}_{2} \mathrm{O}_{3}, \mathrm{Au}-\mathrm{Fe}_{2} \mathrm{O}_{3}-550$ and $\mathrm{Au}-\mathrm{Fe}_{2} \mathrm{O}_{3}-700$; (d) summary of significant PEC parameters of pristine $\mathrm{Fe}_{2} \mathrm{O}_{3}, \mathrm{Au}-\mathrm{Fe}_{2} \mathrm{O}_{3}-550, \mathrm{Au}-\mathrm{Fe}_{2} \mathrm{O}_{3}-700$ samples.

than $10 \%$ in the visible light $(14.1 \%$ at $420 \mathrm{~nm})$.

In addition, we also investigated the effect of $\mathrm{Au}$ ion implantation dosage on PEC water splitting performance. As seen in Fig. $3 c$, the sample with the implantation dosage of $5 \times 10^{16}$ ions $\mathrm{cm}^{-2}$ exhibits the best PEC water splitting performance. It is considered that smaller implantation dosage resulted in fewer $\mathrm{Au}$ particles and $\mathrm{Fe}^{2+}$ species, meanwhile, over-dosage implantation sputtered too much hematite, which led to degradation of overall photoactivity. We also studied the effects of different annealing temperatures on the PEC performance of Auimplanted $\mathrm{Fe}_{2} \mathrm{O}_{3}$ samples (Fig. S4). Results suggest the lower temperature annealing process (at 350 and $450^{\circ} \mathrm{C}$ ) exhibited poor PEC water splitting performance, because lower temperature annealing cannot well repair the lattice damage caused by $\mathrm{Au}$ ion implantation. Finally, we tested I- $t$ curves of $\mathrm{Au}-\mathrm{Fe}_{2} \mathrm{O}_{3}-700$ for 8-hour (Fig. 3d), and impressively, the photocurrent density remained stable, indicating the excellent stability of $\mathrm{Au}-\mathrm{Fe}_{2} \mathrm{O}_{3}-700$ sample.

To find out the enhancement mechanism of Au-im- planted $\mathrm{Fe}_{2} \mathrm{O}_{3}$, electrochemical impedance spectroscopy (EIS) was tested firstly for pristine $\mathrm{Fe}_{2} \mathrm{O}_{3}, \mathrm{Au}-\mathrm{Fe}_{2} \mathrm{O}_{3}-550$, and $\mathrm{Au}-\mathrm{Fe}_{2} \mathrm{O}_{3}-700$ at the potential $1.5 \mathrm{~V}$ vs. RHE (Fig. 4a). The Nyquist diagram of each sample shows an apparent semicircle, which is mainly associated with charge transfer resistance $\left(R_{\mathrm{ct}}\right) . R_{\mathrm{ct}}$ values were fitted by a simple Randle circuit model shown in the inset of Fig. 4a. $R_{\mathrm{ct}}$ values of $\mathrm{Au}-\mathrm{Fe}_{2} \mathrm{O}_{3}-550$ and $\mathrm{Au}-\mathrm{Fe}_{2} \mathrm{O}_{3}-700$ (Fig. 4d) are much smaller than that of pristine $\mathrm{Fe}_{2} \mathrm{O}_{3}$, indicating that the Au-implanted samples obtained much better electrical conductivity, which can be resulted from the synergistic effects of $\mathrm{Fe}^{2+}$ species and $\mathrm{Au}$ particles. To get more deeply insight into the enhancement mechanism, we measured the charge separation and charge injection efficiency using the $\mathrm{H}_{2} \mathrm{O}_{2}$ as the hole scavenger in the electrolyte $[30,48]$. The charge separation efficiency was calculated with the following equation:

$$
\eta_{\text {charge separation }}=J_{\mathrm{H}_{2} \mathrm{O}_{2}} / J_{\text {absorbed }} \text {, }
$$

where $\eta_{\text {charge separation }}$ is the charge separation efficiency of 
the photogenerated carriers, $J_{\mathrm{H}_{2} \mathrm{O}_{2}}$ is photocurrent density under the $458 \mathrm{~nm}$ monochromatic light at $1 \mathrm{~mol} \mathrm{~L}^{-1}$ $\mathrm{NaOH}+0.5 \mathrm{~mol} \mathrm{~L}^{-1} \mathrm{H}_{2} \mathrm{O}_{2}$ electrolyte, and $J_{\text {absorbed }}$ is the power density of irradiance of $458 \mathrm{~nm}$ monochromatic light. The charge injection efficiency was calculated with the following equation:

$$
\eta_{\text {charge injection }}=J_{\text {light }} / J_{\mathrm{H}_{2} \mathrm{O}_{2}} \text {, }
$$

where $\eta_{\text {charge injection }}$ is the charge separation efficiency of the photogenerated carriers, $J_{\text {light }}$ is photocurrent density under the AM $1.5 \mathrm{G}$ illumination at $1 \mathrm{~mol} \mathrm{~L}^{-1} \mathrm{NaOH}$ electrolyte, and $J_{\mathrm{H}_{2} \mathrm{O}_{2}}$ is photocurrent density under the AM $1.5 \mathrm{G}$ illumination at $1 \mathrm{~mol} \mathrm{~L}^{-1} \mathrm{NaOH}+0.5 \mathrm{~mol} \mathrm{~L}^{-1}$ $\mathrm{H}_{2} \mathrm{O}_{2}$ electrolyte [49]. It can be seen in Fig. 4b, the charge separation efficiency of $\mathrm{Fe}_{2} \mathrm{O}_{3}$ is about $1 \%$, which is consistent with intrinsic properties of hematite as a Mott insulator. By contrast, the charge separation efficiency of $\mathrm{Au}-\mathrm{Fe}_{2} \mathrm{O}_{3}-550$ and $\mathrm{Au}-\mathrm{Fe}_{2} \mathrm{O}_{3}-700$ was elevated to be about $6 \%$. Meanwhile, the charge injection efficiency of pristine $\mathrm{Fe}_{2} \mathrm{O}_{3}$ was lower than 4\% (Fig. 4c), while that of Au$\mathrm{Fe}_{2} \mathrm{O}_{3}-550$ was elevated to $25 \%$. Impressively, the charge injection efficiency of $\mathrm{Au}-\mathrm{Fe}_{2} \mathrm{O}_{3}-700$ was greatly increased to $89 \%$. It should be noted that $\mathrm{Au}-\mathrm{Fe}_{2} \mathrm{O}_{3}-550$ and $\mathrm{Au}-$ $\mathrm{Fe}_{2} \mathrm{O}_{3}-700$ have similar charge separation efficiency; however, the charge injection efficiency of $\mathrm{Au}-\mathrm{Fe}_{2} \mathrm{O}_{3}-700$ is much higher than that of $\mathrm{Au}-\mathrm{Fe}_{2} \mathrm{O}_{3}-550$. This suggests that tighter contact between hematite and Au particles can greatly promote photogenerated carrier injection process. Based on a series of characterizations and analyses above, we concluded that $\mathrm{Fe}^{2+}$ species and tightly contacted Au particles can greatly promote the separation and injection of photogenerated carriers. Therefore, the PEC water splitting performance of Au ion implanted $\mathrm{Fe}_{2} \mathrm{O}_{3}$ was significantly enhanced compared with pristine $\mathrm{Fe}_{2} \mathrm{O}_{3}$.

\section{CONCLUSIONS}

In summary, we have employed Au ion implantation and following high-temperature annealing to greatly improve the PEC water splitting performance of hematite. Based on a series of characterizations and analyses, we found that the $\mathrm{Fe}^{2+}$ species and tightly attached Au particles can significantly promote the separation and injection of photogenerated carriers. Particularly, the stronger contact between $\mathrm{Au}$ particles and hematite, formed at higher temperatures, can tremendously improve the charge injection efficiency to $89 \%$ at $1.5 \mathrm{~V} v s$. RHE. Therefore, the photocurrent density of optimized Au-implanted $\mathrm{Fe}_{2} \mathrm{O}_{3}$ can reach $1.16 \mathrm{~mA} \mathrm{~cm}^{-2}$, which is significantly enhanced compared with the negligible photoresponse of pristine
$\mathrm{Fe}_{2} \mathrm{O}_{3}\left(4 \mu \mathrm{A} \mathrm{cm}{ }^{-2}\right.$ at $1.5 \mathrm{~V}$ vs. RHE). Meanwhile, Au-implanted $\mathrm{Fe}_{2} \mathrm{O}_{3}$ photoelectrode exhibited great stability in the 8-hour PEC water splitting test without photocurrent decay. This novel and effective method also has the potential to become a general way to enhance the PEC performance of other PEC materials.

Received 27 August 2017; accepted 5 November 2017;

published online 20 December 2017

1 Wheeler DA, Wang G, Ling Y, et al. Nanostructured hematite: synthesis, characterization, charge carrier dynamics, and photoelectrochemical properties. Energy Environ Sci, 2012, 5: 6682-6702

2 Fujishima A, Honda K. Electrochemical photolysis of water at a semiconductor electrode. Nature, 1972, 238: 37-38

3 Yang C, Wang Z, Lin T, et al. Core-shell nanostructured "black" rutile titania as excellent catalyst for hydrogen production enhanced by sulfur doping. J Am Chem Soc, 2013, 135: 17831-17838

4 Warren SC, Voïtchovsky K, Dotan H, et al. Identifying champion nanostructures for solar water-splitting. Nat Mater, 2013, 12: 842849

5 Liu J, Liu Y, Liu N, et al. Metal-free efficient photocatalyst for stable visible water splitting via a two-electron pathway. Science, 2015, 347: 970-974

6 Qiu Y, Liu W, Chen W, et al. Efficient solar-driven water splitting by nanocone $\mathrm{BiVO}_{4}$-perovskite tandem cells. Sci Adv, 2016, 2: e1501764

7 Morales-Guio CG, Tilley SD, Vrubel H, et al. Hydrogen evolution from a copper (I) oxide photocathode coated with an amorphous molybdenum sulphide catalyst. Nat Commun, 2014, 5: 3059

8 Wu H, Ren F, Xing Z, et al. Cathodic shift of onset potential for water oxidation of $\mathrm{WO}_{3}$ photoanode by $\mathrm{Zr}^{+}$ions implantation. J Appl Phys, 2017, 121: 085305

9 Li Z, Luo W, Zhang M, et al. Photoelectrochemical cells for solar hydrogen production: current state of promising photoelectrodes, methods to improve their properties, and outlook. Energy Environ Sci, 2013, 6: 347-370

10 Han $\mathrm{T}$, Chen Y, Tian G, et al. Hydrogenated $\mathrm{TiO}_{2} / \mathrm{SrTiO}_{3}$ porous microspheres with tunable band structure for solar-light photocatalytic $\mathrm{H}_{2}$ and $\mathrm{O}_{2}$ evolution. Sci China Mater, 2016, 59: 10031016

11 Liu $\mathrm{H}$, Ma H, Joo J, et al. Contribution of multiple reflections to light utilization efficiency of submicron hollow $\mathrm{TiO}_{2}$ photocatalyst. Sci China Mater, 2016, 59: 1017-1026

12 Pozun ZD, Henkelman G. Hybrid density functional theory band structure engineering in hematite. J Chem Phys, 2011, 134: 224706

13 Rozenberg GK, Dubrovinsky LS, Pasternak MP, et al. High-pressure structural studies of hematite $\mathrm{Fe}_{2} \mathrm{O}_{3}$. Phys Rev B, 2002, 65: 064112

14 Glasscock JA, Barnes PRF, Plumb IC, et al. Enhancement of photoelectrochemical hydrogen production from hematite thin films by the introduction of Ti and Si. J Phys Chem C, 2007, 111: 16477-16488

15 Aroutiounian VM, Arakelyan VM, Shahnazaryan GE, et al. Photoelectrochemistry of tin-doped iron oxide electrodes. Sol Energy, 2007, 81: 1369-1376

16 Annamalai A, Shinde PS, Jeon TH, et al. Fabrication of superior $\alpha-$ $\mathrm{Fe}_{2} \mathrm{O}_{3}$ nanorod photoanodes through ex-situ Sn-doping for solar water splitting. Sol Energy Mater Sol Cells, 2016, 144: 247-255 
17 Ling Y, Wang G, Wheeler DA, et al. Sn-doped hematite nanostructures for photoelectrochemical water splitting. Nano Lett, 2011, 11: 2119-2125

18 Abel AJ, Patel AM, Smolin SY, et al. Enhanced photoelectrochemical water splitting via SILAR-deposited Ti-doped hematite thin films with an FeOOH overlayer. J Mater Chem A, 2016, 4: 6495-6504

19 Kay A, Cesar I, Grätzel M. New benchmark for water photooxidation by nanostructured $\alpha-\mathrm{Fe}_{2} \mathrm{O}_{3}$ Films. J Am Chem Soc, 2006, 128: $15714-15721$

20 Li M, Yang Y, Ling Y, et al. Morphology and doping engineering of Sn-doped hematite nanowire photoanodes. Nano Lett, 2017, 17: 2490-2495

21 Ling Y, Wang G, Reddy J, et al. The influence of oxygen content on the thermal activation of hematite nanowires. Angew Chem, 2012, 124: 4150-4155

22 Forster M, Potter RJ, Ling $\mathrm{Y}$, et al. Oxygen deficient $\alpha-\mathrm{Fe}_{2} \mathrm{O}_{3}$ photoelectrodes: a balance between enhanced electrical properties and trap-mediated losses. Chem Sci, 2015, 6: 4009-4016

23 Wang G, Ling Y, Li Y. Oxygen-deficient metal oxide nanostructures for photoelectrochemical water oxidation and other applications. Nanoscale, 2012, 4: 6682-6691

24 Ling $\mathrm{Y}$, Wang $\mathrm{G}$, Wang $\mathrm{H}$, et al. Low-temperature activation of hematite nanowires for photoelectrochemical water oxidation. ChemSusChem, 2014, 7: 848-853

25 Li M, Deng J, Pu A, et al. Hydrogen-treated hematite nanostructures with low onset potential for highly efficient solar water oxidation. J Mater Chem A, 2014, 2: 6727-6733

26 Kiejna A, Pabisiak T. Surface properties of clean and Au or Pd covered hematite $\left(\alpha-\mathrm{Fe}_{2} \mathrm{O}_{3}\right)(0001)$. J Phys-Condens Matter, 2012, 24: 095003

27 Warwick MEA, Barreca D, Bontempi E, et al. Pt-functionalized $\mathrm{Fe}_{2} \mathrm{O}_{3}$ photoanodes for solar water splitting: the role of hematite nano-organization and the platinum redox state. Phys Chem Chem Phys, 2015, 17: 12899-12907

28 Liu W, Liu Z, Wang G, et al. Carbon coated $\mathrm{Au} / \mathrm{TiO}_{2}$ mesoporous microspheres: a novel selective photocatalyst. Sci China Mater, 2017, 60: 438-448

29 Dearnaley G. Ion implantation. Nature, 1975, 256: 701-705

30 Wang G, Xiao X, Li W, et al. Significantly enhanced visible light photoelectrochemical activity in $\mathrm{TiO}_{2}$ nanowire arrays by nitrogen implantation. Nano Lett, 2015, 15: 4692-4698

31 Vayssieres L, Beermann N, Lindquist SE, et al. Controlled aqueous chemical growth of oriented three-dimensional crystalline nanorod arrays: application to iron (III) oxides. Chem Mater, 2001, 13: 233235

32 Liu Y, Ren F, Cai G, et al. Energy dependence on formation of $\mathrm{TiO}_{2}$ nanofilms by Ti ion implantation and annealing. Mater Res Bull, 2014, 51: 376-380

33 Zheng X, Shen S, Ren F, et al. Irradiation-induced $\mathrm{TiO}_{2}$ nanorods for photoelectrochemical hydrogen production. Int J Hydrogen Energy, 2015, 40: 5034-5041

34 Kim JY, Magesh G, Youn DH, et al. Single-crystalline, wormlike hematite photoanodes for efficient solar water splitting. Sci Rep, 2013, 3: 2681

35 de Faria DLA, Venâncio Silva S, de Oliveira MT. Raman microspectroscopy of some iron oxides and oxyhydroxides. J Raman Spectrosc, 1997, 28: 873-878
36 Ding SY, Yi J, Li JF, et al. Nanostructure-based plasmon-enhanced Raman spectroscopy for surface analysis of materials. Nat Rev Mater, 2016, 1: 16021

37 Malviya KD, Dotan $\mathrm{H}$, Shlenkevich D, et al. Systematic comparison of different dopants in thin film hematite $\left(\alpha-\mathrm{Fe}_{2} \mathrm{O}_{3}\right)$ photoanodes for solar water splitting. J Mater Chem A, 2016, 4: 3091-3099

38 Sander D, Schmidthals C, Enders A, et al. Stress and structure of $\mathrm{Ni}$ monolayers on W(110): the importance of lattice mismatch. Phys Rev B, 1998, 57: 1406-1409

39 Li W, Sheehan SW, He D, et al. Hematite-based solar water splitting in acidic solutions: functionalization by mono- and multilayers of iridium oxygen-evolution catalysts. Angew Chem, 2015, 127: 11590-11594

40 Fujii T, de Groot FMF, Sawatzky GA, et al. In situ XPS analysis of various iron oxide films grown by $\mathrm{NO}_{2}$-assisted molecular-beam epitaxy. Phys Rev B, 1999, 59: 3195-3202

41 Morrish R, Rahman M, MacElroy JMD, et al. Activation of hematite nanorod arrays for photoelectrochemical water splitting. ChemSusChem, 2011, 4: 474-479

42 Xiao R, Pelenovich VO, Fu D. Spin cycloid destruction in Pr doped $\mathrm{BiFeO}_{3}$ films studied by conversion-electron Mossbauer spectroscopy. Appl Phys Lett, 2013, 103: 012901

43 Klingelhöfer G, Morris RV, Bernhardt B, et al. Jarosite and hematite at meridiani planum from opportunity's mossbauer spectrometer. Science, 2004, 306: 1740-1745

44 Zheng X, Ren F, Zhang S, et al. A general method for large-scale fabrication of semiconducting oxides with high SERS sensitivity. ACS Appl Mater Interfaces, 2017, 9: 14534-14544

$45 \mathrm{Pu} \mathrm{A}$, Deng J, Li M, et al. Coupling Ti-doping and oxygen vacancies in hematite nanostructures for solar water oxidation with high efficiency. J Mater Chem A, 2014, 2: 2491-2497

46 Turner NH, Single AM. Determination of peak positions and areas from wide-scan XPS spectra. Surf Interface Anal, 1990, 15: 215-222

47 Wang H, Turner JA. Characterization of hematite thin films for photoelectrochemical water splitting in a dual photoelectrode device. J Electrochem Soc, 2010, 157: F173

48 Dotan H, Sivula K, Grätzel M, et al. Probing the photoelectrochemical properties of hematite $\left(\alpha-\mathrm{Fe}_{2} \mathrm{O}_{3}\right)$ electrodes using hydrogen peroxide as a hole scavenger. Energy Environ Sci, 2011, 4: 958-964

49 Xi L, Chiam SY, Mak WF, et al. A novel strategy for surface treatment on hematite photoanode for efficient water oxidation. Chem Sci, 2013, 4: 164-169

Acknowledgements This work was supported by the National Natural Science Foundation of China (51371131, 11375134, 51571153 and 11722543), and the Fundamental Research Funds for the Central Universities (2042017kf0168).

Author contributions He D participated in material preparation and data analysis and drafted the manuscript. Song $\mathrm{X}$ conceived and cowrote the paper. Ke Z performed the data analysis. Xiao X, Jiang C participated in its design and coordination.

Conflict of interest The authors declare that they have no conflict of interest.

Supplementary information Experimental details and supporting data are available in the online version of the paper. 


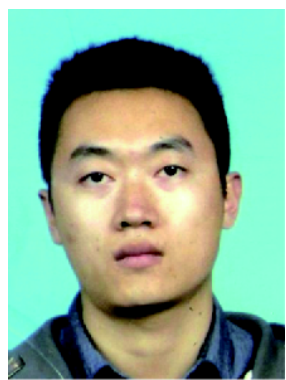

Dong He obtained his bachelaor degree from Hubei University in 2015. He is a $\mathrm{PhD}$ candidate of Wuhan University under the supervision of Profs. Xiangheng Xiao and Changzhong Jiang. His research interests are mainly focused on photoelectrochemical water splitting and electrocatalytic water splitting.

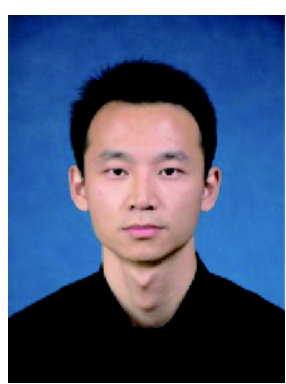

Xiangheng Xiao received his BS degree and PhD degree from Wuhan University. He worked as a visiting scholar at the Department of Chemistry and Biochemistry, University of California, Los Angeles, from 2013 to 2014. Currently, he has been a full professor in the Department of Physics, Wuhan University, since 2015. The research fields are mainly focused on photoelectrochemical water splitting, surface-enhanced spectroscopy, nanophotonics and ion beam modification of nanoscale material devices. For details please see the lab website: http://physics.whu.edu.cn/xiaoxiangheng.

\section{使用离子注入产生金颗粒和 $\mathrm{Fe}^{2+}$ 显著增强 $\boldsymbol{\alpha}-\mathrm{Fe}_{2} \mathrm{O}_{3}$ 光电化学性能}

贺拣, 宋先印, 柯尊健, 肖湘衡, 蒋昌忠

摘要 光电化学催化分解水是一种极具发展前景的生产 $\mathrm{H}_{2}$ 和 $\mathrm{O}_{2}$ 的方法. $\alpha-\mathrm{Fe}_{2} \mathrm{O}_{3}$ 由于其具有优良的光电化学稳定性、无毒害、地球储量大 以及合适的能带宽度 $E_{\mathrm{g}} \sim 2.1 \mathrm{eV}$ 等优点, 被认为是最有潜力的光电催化分解水的材料之一. 然而由于其空穴传输距离短 (约 $2 \sim 4 \mathrm{~nm}$ )、导电 性差、光生载流子复合速度极快等原因, $\alpha-\mathrm{Fe}_{2} \mathrm{O}_{3}$ 的光电催化分解水的效率受到了极大限制. 在此, 我们报道了一种新颖并且高效的离子注 入 $\mathrm{Au}$ 元素并且退火的方法显著提高了 $\alpha-\mathrm{Fe}_{2} \mathrm{O}_{3}$ 光电化学分解水的效率. 根据一系列的表征和分析, 发现 $\mathrm{Fe}^{2+}$ 和紧密接触的金颗粒在金注入 的 $\alpha-\mathrm{Fe}_{2} \mathrm{O}_{3}$ 样品中产生. 因此, 金注入的 $\alpha-\mathrm{Fe}_{2} \mathrm{O}_{3}$ 样品的载流子分离效率和注入效率得到了显著提高. 该样品光电流密度在 $1.5 \mathrm{~V} v \mathrm{~s}$. RHE偏压 下可以达到 $1.16 \mathrm{~mA} \mathrm{~cm}$, 相对原始样品光电流密度提升接近 300 倍 $\left(4 \mu \mathrm{A} \mathrm{cm}^{-2}\right)$. 此外, 金注入的 $\alpha-\mathrm{Fe}_{2} \mathrm{O}_{3}$ 样品在 $8 \mathrm{~h}$ 的光电催化分解水的测 试中没有出现光电流衰减的现象, 表现了良好的稳定性. 